\title{
Az Andok térsége: történeti és földrajzi áttekintés
}

\section{Földrajzi és etno-demográfiai útmutató}

Jelen kötet tanulmányai a Középsô-Andok országainak, azaz Ecuador, Peru, Bolívia társadalmi kérdéseivel foglalkoznak. Két térképvázlattal szeretnénk segíteni a könnyebb eligazodást a különbözó etnikumok és földrajzi régiók között. Az elsô Tawantinsuyu, az Inka Birodalom „közúti térképe”, a legfontosabb inka utak és városok feltüntetésével. A térkép a történész Espinosa Soriano vízióját tükrözi a Birodalomról, amely szerinte alapvetôen különbözött az óvilági birodalmaktól. Nem voltak szomszédos államalakulatok, éppen ezért nem voltak országhatárok sem. Nem lehet megállapítani, meddig terjedt a Birodalom, csak azt, hogy merre vezettek a legfontosabb útvonalak, és hol épültek olyan városok, ahol az élet éppen úgy az inka életvitel és szokásrend szerint zajlott, mint a fơvárosban, Qosqóban (Cuzco).

A térképen feltüntettük a mai országhatárokat. Látható, hogy a Birodalom alapvetóen a Hegyvidéken (Sierra) és a Tengerparton (Costa) épült ki, a mai Ecuador, Peru, Bolívia, Észak-Chile és ÉszakArgentína területén. Ezeken a területeken már a spanyolok megérkezése elôtt nagy lélekszámú földmúves népesség élt, ôk képezték a Birodalom alattvalóit. Az Inkák a gyors kecsuásítás politikáját követték: ennek keretében népcsoportokat költöztettek sok ezer kilométerre eredeti lakóhelyüktól, kecsua nyelven oktattak, és ez volt a hadsereg nyelve is. „Peru általános nyelve” a gyarmati korban is az adminisztráció és a hittérítés legfontosabb médiuma maradt. Azokon a területeken, amelyekre a Birodalom kiterjedt, 
ma is jelentôs kecsua ajkú népességet találunk. Becslések szerint a kilencvenes években az említett öt országban összesen körülbelül 10-12 millió ember beszélt kecsuául.

A korábban nagy lélekszámú óshonos csoportok közül az ajmara anyanyelvúek számát a különbözô becslések ma egy-és hárommillió fố közöttire teszik. Az elsôsorban Bolíviában élô ajmarák mozgalma a kilencvenes évekre jelentôs politikai tényezôvé vált, szövetségük még az országos választásokon is sikereket könyvelhetett el. A más andokbeli nyelveken beszéló népcsoportok (uru, pukina, tszacsila, chachi és mások) csak nyelvi szigetként élnek tovább, néhány ezer, esetleg néhány tízezer foore tehetô a számuk.

A második térkép a különbözô hegyvidéki és tengerparti etnikai csoportok, pontosabban a nyelvi csoportok földrajzi elhelyezkedését mutatja be napjainkban. Tájékozódási pontként elsôsorban azoknak a városoknak és földrajzi régióknak a nevét tüntettük föl, amelyek a jelen kötetben közölt tanulmányokban is szerepelnek. A térképvázlatról a tengerparti spanyol ajkú és a hegyvidéki (spanyol ajkú, kecsua, ajmara, pukina és uru) csoportok elhelyezkedését lehet leolvasni. Igyekeztünk jelezni, hogy a városok jellemzóen nem kecsua ajkúak, de ha azt akarnánk, hogy a térkép tökéletes legyen, az Andok majd' valamennyi városát mentesíteni kellene a satírozás alól. A térképen nem tudtuk föltüntetni, hogy egyes területeken mekkora lehet a kecsua és ajmara többség vagy kisebbség aránya (errôl ugyanis nem is állnak rendelkezésre pontos adatok), így a satírozott terület inkább azt jelzi, hol érvényesül még kecsua vagy ajmara befolyás, és hol nem. Nem tüntettük fel a kulturális és foglalkozási vagy nyelvidialektusbeli különbségeket, pedig ezeket mind a spanyol, mind a kecsua kapcsán sok nyelvész és antropológus fontosnak tartja.

Vázlatunk tulajdonképpen egy kelet-európai szemléletú Andoktérkép, amely az országhatárokon átnyúló nyelvi-nemzetiségi össze- 
tartozást sugallja, holott az ilyen összetartozás-tudat még távolról sem általános. Tudomásunk szerint a miénkhez hasonló szemléletû térképvázlat még nem készült az Andokról.

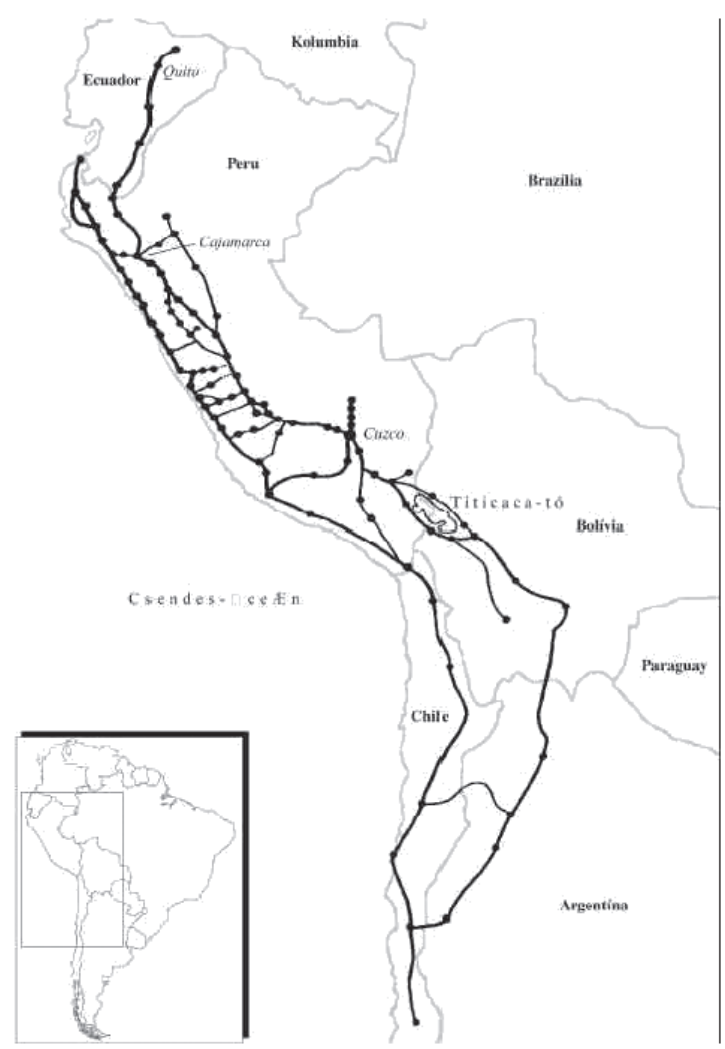

1. térkép

Az Inka Birodalom a mai országhatárok föltüntetésével, Espinosa Soriano nyomán 


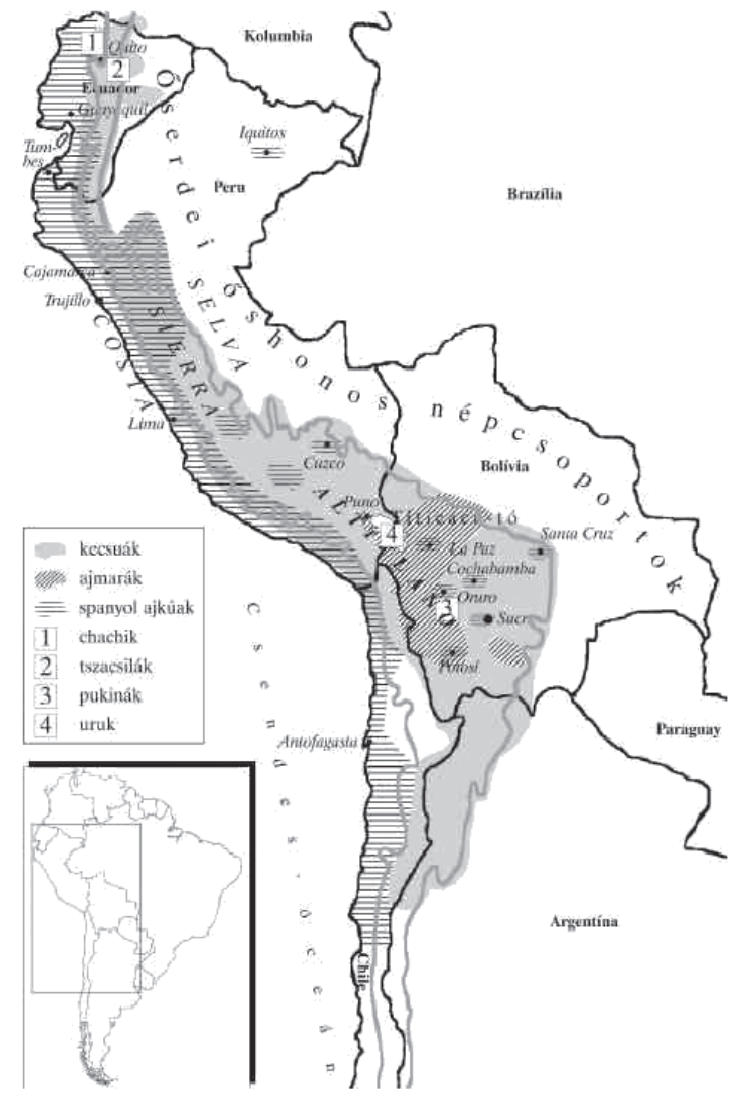

\section{2. térkép}

A nyelvi-etnikai csoportok elhelyezkedése napjainkban a Középsố-Andokban 


\section{Történeti áttekintés}

Jelen áttekintés olyan olvasó számára íródott, akirôl feltételezzük, hogy keveset vagy éppen semmit sem tanult még az Andok történelmérốl. A hazai történelemoktatás keretein belül általában az Európán kívüli népekrôl, kultúrákról nagyon kevés szó esik, és nem tanulhatunk sokkal többet a latin-amerikai országok múlt századi történelmérôl sem.

Néhány oldalas áttekintésünk sajnos mindenképpen felületes lesz egy felkészült, a témát ismerô olvasó számára, de remélem, hogy be tudja tölteni azt a célt, hogy az érdeklôdônek egyfajta elsố benyomása alakuljon ki az Andok történelmérốl. Jelen áttekintés kimondottan konzervatív szemléletú, mintha az andokbeli elemi iskolai tankönyvek lapjairól lépett volna le; remélem azonban, hogy a szöveggyújtemény többi írása meggyốzi az olvasót, hogy vannak más, ettôl jelentôsen eltérô, korszerúbbnek tekinthetố történelemfelfogások is.

\section{Kolumbusz elốtti kultúrák}

Amerika benépesülése Ázsia felôl Kr. e. 40000 körül kezdôdhetett meg, s a dél-amerikai kontinens társadalmi fejlôdése az óvilághoz képest óriási késéssel indult. Az elsô megtelepedett, földmûves tevékenységet végzố emberi csoportok az Andokban a régészet adatai szerint az idôszámításunk elốtti II. évezredtốl datálhatók. Ez idôtoól fogva az Andokban vadász- és földmúves társadalmak, harcos nemzetségek, törzsek, államalakulatok emelkedtek fel, majd túntek el az egymást követố háborúk és népvándorlások következtében. Az elbukott civilizációk kulturális vívmányai azonban tovább éltek a falusi emberek hagyományaiban, a vallásban, a papság tudásában. Ez segített nemzedékrôl nemzedékre átörökíteni a terület sajátos kultúráját, a múvészet megkülönböztetố stílusjegyeit. 
Az idôk folyamán az Andok térségében jó néhány kiemelkedô kulturális térség alakult ki. Az egyszerúsítés igénye miatt (azaz, hogy az olvasó egy vázlatos képet kapjon, amit jobban megjegyezhet, de távolról sem pontos) ezeket területi alapon négy csoportba soroljuk: a középsô andesi hegyvidéken és a tengerparton az északi és a déli térségeket. E kulturális áreák az idôk folyamán olykor kapcsolatba kerültek egymással, de ábrázoló- és díszítômúvészetük mindvégig megôrizte eredeti stílusjegyeit. Az északi és a déli kultúrák ornamentikáinak karakterjegyei nagyon különbözôk, míg a közbülsốk általában bizonyos átmenetet képeznek. Az egyszerúsítés igénye miatt minden kulturális területrôl egyegy markáns, jól megragadható kultúrát emelek ki, ami sajnos azzal jár, hogy jó pár értékes régészeti lelôhely még említésszinten sem kerül bemutatásra.

A spanyol hódítás eloott 300 évvel, az andokbeli indián civilizációk utolsó fejezetében az Inkák megjelenése váratlan és addig nem tapasztalt mértékú gazdasági és társadalmi változásokat eredményezett, egyesítette és kölcsönhatásba hozta az Andok korábbi kulturális térségeit. (Mivel az Inka megnevezés nem népnév - az Inka Birodalom lakói kecsua, ajmara és más óshonos népek voltak -, hanem az uralkodó család neve, mai fogalmaink szerint egy nemzetségi név, melyet több Inka leszármazott - például Garcilaso de Vega - családnévként is használt, az Inka szót jelen kötetben, a megfeleló értelmi környezetben következetesen nagybetúvel írjuk.)

\section{A perui Andok északi vidéke: Chavín}

Az Andok fiatal lánchegység, amelynek láncai észak és dél felé a kontinens teljes hosszában, kelet-nyugati irányban viszont csak néhány száz kilométer szélességben húzódnak. A perui tengerpart felól közeledve a hegyek meredeken emelkednek sok ezer méteres magasságba. Óriási tömegüket keskeny folyóvölgyek tagolják. 
Az oxigénszegény, hideg éghajlatú hegyvidéken a folyók az életet viszik a kietlen tájba; keskeny partjaik sok munkával megmúvelhetốvé tehetốk. A Marañón folyó vízgyújtô területén fekszik Chavín de Huántar romvárosa.

E kultúra gyökerei egyelôre teljességgel ismeretlenek számunkra. A régészek a '60-as években azzal a meglepố ténnyel találták szembe magukat, hogy a perui hegyekben olyan lelóhelyet sikerült feltárniuk, amely minden valószínúség szerint egy egykor fejlett társadalom gazdasági, politikai és kulturális központja lehetett. Semmi nyomot nem találtak azonban, ami a kezdetekre utalt volna.

Egyes kutatók szerint ez a kultúra az Amazonas menti ôserdóben alakult ki, és a hajdani birodalom csapatai késóbb, elfoglalva a magas hegyek termékeny völgyeit, oda tették át székhelyüket. Mivel az ôserdốben nincsenek sziklák, e népek a feltételezés szerint fából építkeztek, ezért anyagi kultúrájuk az évezredek során elenyészett.

Chavín de Huántar romjait a '60-as évektốl fogva ismerjük. Ez a lelôhely néhány nagy teraszból és üregekbe vésett, falazott helyiségekbốl áll. A legelsố leletek Kr. e. 1000-re datálhatók. A régészeti emlékeket nagyon kemény, vulkanikus kövekbe faragott, hihetetlenül pontos és szép vonalú, bonyolult rajzolatok jellemzik. A rajzokon a jaguár és a madár - talán hárpia, vagy kondorkeselyú jelképei uralkodnak. Ezen istenségek kezében vagy fejdíszeként gyakran kígyókötegeket láthatunk. Kígyókból formázták a rajzolók az embert idézó alakok haját, fülét is. A képeken dominánsak az erô jelképei: a hatalmas agyarak, karmok. Kiemelkedô szerepet kap a száj, a villogó fogak, melyek egy ábrázoláson több helyen is feltúnnek. Egy-egy szájból gyakran emberi vagy állati testrészek kanyarognak elô. Chavín de Huántar kultúrája idôszámításunk kezdete körül elbukott, de hatása még sokáig tartott. Ornamentikus múvészetének markáns stílusjegyei a késôbbi korok régészeti emlékein is fellelhetôek. 


\section{Észak-perui tengerpart: Moche és Chimú}

Peru tengerpartja elôtt folyik el az Antarktisz felôl érkezô, hideg vizú Humboldt-áramlat. A hideg víz áldás és csapás is a tájra. Áldás, mert a hideg vízben sok tengeri moszat és plankton él, ami rengeteg halat vonz e vidékre, és biztos megélhetést nyújt a halászoknak. Csapás, mert a hideg víz alig párolog, így a vidék fölött nincs felhôképzôdés: Peru és Chile tengerpartja a világ egyik legszárazabb sivataga. A természeti adottságok, a jó halászati lehetóségek már a korai idókben sok embert vonzottak az elhagyatott folyóvölgyekbe. A völgyekben öntözéses földmúvelést is végeztek.

A csatornák építése sok ember összefogását igényelte, és ez erôsen szervezett társadalmak kialakulásához vezetett. A Moche, vagy más néven Mochica állam legrégebbi kultúrrétegei Kr. e. háromszázból származnak. A birodalom csillaga az idôk során többször lehanyatlott, de végül mindig megerôsödve emelkedett fel. A régészek öt fontos korszakot különböztetnek meg, elsôsorban a kerámiaedények és azok festésének stílusa alapján.

A sós, száraz tengerparti homok tökéletesen konzerválta az utókor számára azokat a szôtteseket, fafaragásokat, amelyek más talajban elbomlottak volna. Az ezeréves temetôkben a régészek nem a halottak csontvázait találják, hanem szinte ép múmiájukat. Múzeumi gyưjtemények ôriznek olyan ép szövôszékeket, hogy a rajtuk levô, félbemaradt textíliát tovább lehetne szôni. A bôséges leletanyag alapján e kultúrát már jobban ismerjük.

A mochica kerámiafestés jellemzói a rajzolt, finom vonalak, a pontos ábrázolás. A kerámiákat nagy mennyiségben készítették, s a mindennapi élet összes eseményét megörökítették rajtuk. Mélységes realizmussal ábrázolták a beteg, púpos, vak embereket, a szerelmes jeleneteket is. E kultúra messze északra és dél felé is hatott. Az itt érlelt motívumokkal Ecuadorban és a Lima folyó völgyében is találkozhatunk. 
A legutolsó mochica korszak Kr. u. 800-ig tartott. Utána több városállam egyesüléséból megalakult a Chimú birodalom. A csimuk jórészt átvették a mocsikák kultúráját. Vallásuk középpontjában Naymlap isten állt, akit gyakran szertartási aranykések markolatán ábrázoltak. A késeket feltételezhetôen emberáldozatokhoz is használták. A csimuk fốvárosa, Chan-Chan a mai Trujillo mellett több százezer lakost számlált. Autonómiájukat az Inkák, sốt, a XVII. századig a spanyolok alatt is megốrizték. A spanyolok az ô földjükön léptek elôször Peru partjára. Az azt követố évszázadok alatt a csimukat kiirtották vagy asszimilálták.

\section{Dél-perui tengerpart: Nazca és Paracas}

E kulturális térség két legfontosabb központja a Nazca-fennsík kietlen kôsivataga, és a Paracas-félsziget terméketlen homoksivataga volt. E két letûnt kultúra nem csupán a régészek, de a tudományosfantasztikus regények íróinak is kedvelt vadászterülete.

A Nazca-fennsík arról híres, hogy e hatalmas kopár fennsíkon hihetetlen nagy ábrákat és tökéletesen egyenes vonalakat rajzoltak a talajba az ismeretlen elôdök. Az ábrákat óriási méreteik miatt nem is lehet látni a földrôl, csupán a levegóbốl, illetve a környezó hegyoldalakról. A sivatag kövei között a régészek törött és ép edények ezreit találták meg. Bár nyilvánvaló, hogy a fennsíkon sohasem állhatott város, az edényekbôl sok százezer ember étkezhetett és ihatott volna. A kerámiák formája nem olyan változatos, mint Moche kerámiái, de festésük mindennél pazarabb. Rengeteg idôálló színt használtak, csodálatos arányérzékkel rajzoltak. Absztrakt ábrázolásaik az elvonatkoztatni tudás legmagasabb szintjeit képviselik.

Ami Nazca a kerámiában, az Paracas a szốttesekben. A tengerparti félsziget sós homokja két fontos lelóhelyet ôrzött meg nekünk. Az ôsibb, Paracas Cavernas az idôszámításunk elốtti II. évezredbốl származik, Paracas Metropolis pedig Kr. e. 300-ból. Mindkettố a 
világ legnagyobb temetói közé tartozik. Semmi olyan nyomot nem sikerült azonban felfedezni, amely a kezdetekre, a kultúra kialakulására utalt volna.

A leletanyagok alapján Nazca és a két Paracas múvészeti stílusát nagyon hasonlónak találjuk. A paracas-félszigeti lelóhelyekrôl rengeteg szôttes került elô, melyeket a sós homok épen ôrzött meg számunkra. A szốttesek java része polikróm technikával készült. Színviláguk, sokféleségük és lágyságuk, puhaságuk joggal ejtenek minket ámulatba. Gyakran nem az anyagot, hanem a fonalat festették. Úgy szôttek, mintha ecsettel festettek volna: kicsi alakokat, embereket, démonokat, hétköznapi és absztrakt jeleneteket örökítettek meg bámulatos technikai tökéllyel. A szövetek nem csupán sodrott fonalból, de tollból, denevérszốrbôl is készülhettek, s gyakran díszítették gyöngyökkel is.

Paracas és Nazca kisugárzása nem terjedt ki nagy területre, ott viszont meghatározó volt: Ancón, Ica és Chancay múvészetére is e stílusjegyek jellemzóek. A terület a Warí-korszakban, Kr. u. 800 körül a hegyvidéki birodalom uralma alá került. Ekkor jelent meg itt az ún. parti-Tiahuanaco stílus. Warí bukása után e terület újra ôsi stílusát követte, majd az Inka-kor megint hegyvidéki elemeket hozott múvészetébe. A terület lakossága jórészt áldozatul esett a spanyol hódításnak, és az azt követố járványoknak. Ma a dél-perui tengerpartot elsôsorban a fehérek, a rabszolgaként idehurcolt feketék, és hegyvidékrôl ideszármazott indiánok utódai lakják.

Paracas területén egy évezreddel késốbb, a Warí-idôszakban és az Inka-korban a Nap-kultusz legfontosabb zarándokhelye alakult ki. Többen feltételezik, hogy a közvetítố szerepet betöltố kecsua nyelv a paracasi zarándokok találkozásainak alkalmával egyszerúsödhetett olyanná, amilyennek ma ismerjük. 


\section{Dél-andesi magasföld: \\ Tiahuanaco, a Warí- és az Inka-kor}

A negyedik kulturális áram az Andok zord éghajlatú déli területein alakult ki. A Magasföldön, azaz az Altiplanón a viszonylag sík terep nem kedvezett a falusi önellátásnak. A természeti adottság nemcsak a kiterjedtebb kereskedelmet tette lehetôvé, de azt is, hogy egyes népcsoportok másokat leigázzanak, s tartósan ellenôrzést gyakoroljanak felettük. Az idók során a pukinák, az uruk, az aymarák, és a kecsuák uralták ezt a területet. Hatalmukat gyakran új népvándorlások törölték el a föld színérôl. Az Altiplano ma is az indián népcsoportok, nyelvek és kultúrák gazdag tárháza.

A fennsík szíve a Titicaca-tó, a világ legmagasabban fekvô tava. Mítoszok és mesék tömegei kapcsolódnak a rejtélyes tóhoz, amely mindmáig ôrzi titkait, akárcsak a spanyolok elól habjai közé menekített inka aranykincseket. A tó déli partján fekszik Tiahuanaco romvárosa. A kultikus központ már a kezdeti idôktôl fogva kiemelkedett a többi város közül. Fénykorát a klasszikus periódusban, az idôszámításunk szerinti elsô évezredben élte. A város épületei hatalmas, földrengéseknek ellenálló kôtömbökbôl álltak. Leghíresebb építménye a Napkapu, a világ legnagyobb egyetlen kôbôl faragott szobra. Egy kaput mintáz, melynek félfáján faragott fríz fut végig. Ennek központi figurája Viracocha, a Napisten.

Még az elsố évezredben történt, hogy talán az aymarák térnyerése következtében megdôlt az uru indiánok országa. A korábbi államalkotó népet a hódítók elüldözték. Java részük eldugott folyóvölgyekbe menekült, egy csoportjuk pedig a szentként tisztelt Titicacatóra. A tavon növô nádat levágták, a tó közepére hordták, s az így kialakított mesterséges szigeten letáboroztak. Ma is ott élnek. Évrôl évre új réteg nádat tesznek a régire, amire azért van szükség, mert a régi nádszálak fokozatosan megszívják magukat vízzel, elnehezednek, és lassan elsüllyednek. Az uruk szigetén ma is minden nádból készül: a házaik, a csónakok, a gyermekjátékok. 
Kr. u. 800 körül egy új birodalom katonái hódították meg a fennsíkot. A hódítók észak felól érkeztek, a birodalom politikai központja a távoli Warí lett. E birodalom uralma alatt egyesítette az egész Altiplanót, terjeszkedett északra, a perui Andok vidékére, s elfoglalta a tengerparti Ica, Chancay, Nazca vidékét. Mindezekre a területekre elvitte Tiahuanaco kultúráját, a teraszos és az öntözéses földmúvelés technikáját, és államnyelvét, mely valószínúleg az ajmara egyik dialektusa volt. Késôbb a Warí Birodalom bukásával jó idốre elbukott a Tiahuanaco kultúra is. A birodalom elkergetett urai, mint egykor az uruk, elbujdostak, megközelíthetetlen, távoli völgyekben kerestek menedéket. Valószínú, hogy ilyen bujdosókból állt az Inka-nemzetség is, akik - eredetmítoszuk szerint - a Titicacató partjától vándoroltak a Cuzco-medencéig. Történetük a Kolombusz elôtti Andok históriájának utolsó fejezete.

Az inkák családja 1100 körül telepedett meg a Cuzco-medencében. Hamarosan a helyi lakosság vezetôivé emelkedtek, s az elsố inka, a Nap fia, Manco Capac megalapította Cuzco városát, a Világ Köldökét. Az inkák a XIV. század közepétôl kezdve alig 150 év alatt meghódították az Andok és a tengerpart java részét, a mai Kolumbiától egészen az argentín pampáig. A birodalom lakosainak többsége a kecsua vagy az ajmara nyelvet beszélte. E kettô a spanyolon kívül ma is az Andok legfontosabb nyelve. A hivatalos nyelv a kecsua, azaz a runa szimi volt. A hatalmas birodalom egyesítette a négy leírt kulturális térséget is, és felgyorsította közöttük a gazdasági és kulturális érintkezés folyamatát. A múvészeti életet ez a kor sok új vonással gazdagította. Megszületett a hajlékony runa szimi nyelven alapuló udvari költészet, amely az inka-kori színjátszás és a zenei élet alapja lett.

A kor tárgyi múvészete részben a tiahuanacói kultúra hagyományait követi. Ez megmutatkozik az inka építészet nagyszerú, monumentális jellegében is. Más területeken viszont élesebben figyelhetôek meg a korszakváltás jelei. A birodalom és a hadsereg igényeinek kielégítésére megjelent a tömegtermelés. A háziipart az 
állam elôírások, szabványok bevezetésével szervezte újjá. A kor textilés kerámiamúvészetének ornamentikái leegyszerúsítettek, geometriai mintájúak.

Az inkák idején az ötvösmúvészet szakrális tevékenység volt. Alkotásaira a nemesfémek alaposan munkált, magas technikai tudásról árulkodó feldolgozása a jellemzô. A kegytárgyként készített aranyés ezüstszobrocskák ég felé kívánkozó, elnyújtott alakjai a kor jellegzetességei.

A birodalom virágzásának 1532-ben a spanyolok hódítása vetett véget.

\section{Konkviszta és spanyol gyarmati uralom}

Több sikertelen elôzmény (1524, 1526) után Francisco Pizarro partraszállásával (1532) kezdốdött meg az Inka Birodalom spanyol hódítása, azaz a konkviszta. Az elsố esztendố történetét magyar nyelven is sok helyütt megírták: Francisco Pizarro alig száz emberével a tengerpartról Cajamarcába vonult, ahol találkozott az uralkodóval, Atahualpával, aki épp akkoriban vívta ki a gyốzelmet a testvére, Huáscar ellen viselt polgárháborúban. A spanyolok Atahualpát egy merész rajtaütéssel foglyul ejtették, miközben saját táborukat egy tízezer fốs inka hadsereg vette körül. A két fél hónapokon keresztül sakkban tartotta egymást; eközben Atahualpa a spanyol táborból irányította a birodalmat (egyebek közt meggyilkoltatta Huáscárt, akit Cuscóban tartottak fogva), a spanyolok pedig kisebb csapatokkal merész akciókat hajtottak végre (pl. Gonzalo Pizarro és néhány társa, több tízezer zarándok és a helyi papság ellenállását letörve kirabolta a pachacamaci zarándokhelyet). A spanyolok idốközben erôsítést kaptak, és mivel már nem volt szükségük Atahualpára, megfojtották, annak ellenére, hogy az uralkodó elôzốleg minden követelésüket teljesítette, így pl. felvette a kereszténységet, telehordatott egy nagy termet arannyal. 
A spanyolok katonai fölénye vitathatatlan volt: a konkviszta éveiben a néhány tucat vagy legfeljebb néhány száz fôs spanyol csapatok sorozatosan arattak látványos gyôzelmeket a sok ezer, olykor tízezer fôs inka alakulatok felett. Sikerük oka részben politikai (az inka hadsereget demoralizálta a polgárháború, majd uralkodójuk túszul ejtése, végül a sorozatos vesztes csaták) részben technikai jellegú. Elsôsorban nem is a kezdetleges túzfegyverek vagy a feltételezett ijedelem volt az inka hadak sorozatos kudarcának oka, hanem az európai harcmodor, a lovasság, a páncélzat, a dárda és a kard használata: mindezek teljesen ismeretlenek voltak az Andokban. A konkviszta néhány év alatt befejezôdött, az egykori Inka Birodalom területe spanyol alkirályság lett. Az Inka Birodalomtól délre fekvô területek (Chilében Araukánia, a Bio-Bio folyótól délre, Argentínában pedig Patagónia), a XIX. századig de facto függetlenek maradtak. Araukánia ôslakói, a mapuchék Chilében ma is jelentôs kisebbséget alkotnak; Patagónia népeit viszont 1878-79-ben Julio Argentino Roca tábornok népirtó hadjáratban semmisítette meg.

A spanyol kincstárnak küldött aranykincseknek köszönhetôen a szegény sorból származó, analfabéta Francisco Pizarro nemességet és alkirályi címet kapott, 1535-ben megalapította az új fóvárost, a tengerparti Limát, magánvagyonából pedig szülőfalujában, az estremadurai Trujillóban egy székesegyház méretú templomot építtetett. A spanyol gyarmati berendezkedést elóbb egy inka felkelés rázta meg (II. Manco Inka felkelése Cuscóban 1537-ben), majd a hódítók egymás elleni harca (Francisco Pizarrót például 1541-ben, limai otthonában gyilkolta meg a konkvisztádorok rivális csoportja), majd egy, a koronától független gyarmat létrehozására törekvố összeesküvés (Gonzalo Pizarro felkelés, 1544).

$\mathrm{Az}$ évtizedeken át tartó politikai káosznak Francisco de Toledo alkirály vetett véget, aki 1569-1581 közötti kormányzása alatt kialakította a gyarmati uralom alapjait. Ennek részeként 1572-ben leszámolt az ôserdei rejtekébe, Vilcabambába visszavonult inka miniállammal, az utolsó uralkodót, Tupac Amarut pedig Cusco fôterén 
kivégeztette. Rendeletileg tiltotta az inka múlt és indián hagyományok megtartását, és ezzel egyidejúleg megerôsítette a katolikus missziókat, segítette a városok kialakulását, egyetemeket alapított. Nem bízott a spanyol birtokosokban sem, ezért valódi birtokok helyett ún. encomiendák létesültek, amelyeknek nem tulajdonosa, hanem kezelóje volt. Az indián származású nemesek, a kurakák a spanyolokéhoz hasonló jogokat kaptak, de nem keveredhettek; az egymással szembenálló két elit volt a gyarmati uralom egyik alapja, amelyben az alkirály töltötte be a mérleg nyelve szerepét. Toledo idejében kezdték el kiaknázni a Potosí környékén található ezüstbányákat, melyek hozama meghatározó lett a nemesfém-kivitelben az egész gyarmati idôszak alatt. A bányamúvelés munkaerốszükségletének kielégítésére Toledo alkirály felelevenítette az inkakori kényszermunka, a mita intézményét, amelynek keretében az évtizedek alatt sok százezer, talán több millió indiánt vezényeltek bányamunkára. Bár tevékenysége évszázadokra meghatározó jelentôségú volt, hútlen kezelés miatt 1581-ben letartóztatták, életét egy spanyol börtönben fejezte be.

Az alkirályságok közigazgatási határai a gyarmati idôszakban néhányszor megváltoztak. A limai alkirályság kezdetben az egész Középsô-Andok területét felölelte, ám 1739-tôl az északi területek Nueva Granada alkirálysághoz, Alto Perú, a mai bolíviai területek pedig 1776-tól (a mai Argentínával és Uruguayjal együtt) a La Plata alki rálysághoz tartoztak.

Bár a gyarmati kor alatt a kereszténység és a spanyol kultúra elsốsége megkérdôjelezhetetlen maradt, az indián elem kulturális reprezentációjára számos lehetôség mutatkozott, elsôsorban az indiánok óriási (több százszoros) számbeli fölénye miatt. A kereszténység felvétele ugyan általános volt, ám az ôshonos lakosság emellett tovább folytatta korábbi vallásos gyakorlatait. A keresztény és az andokbeli vallásos elképzelések összeolvadásának (szinkretizmus) számos változata alakult ki. A kispapok többsége indián származású volt, és a misszió nyelve is hosszú idốn keresztül a kecsua, nem pedig a 
spanyol. A XVII. század folyamán a kecsua nyelv olyan területeken is terjedt, ahol korábban nem volt Inka Birodalom. (A témával kapcsolatban lásd Juan Carlos Estenssoro írását, kötetünkben).

A spanyol gyarmatokon kialakult kasztrendszer (castas) rögzítette azt a sajátos munkamegosztást, hogy a földet alapvetốen az indiánok múvelik, a fehérek pedig többnyire a városokban laknak. Ez az etnikai munkamegosztás jócskán túlélte a gyarmati kort: a paraszt és az indián az Andokban ma is jóformán egyet jelent, a városba költözố indiánoknak pedig legalábbis egy kulturális asszimiláción kell keresztülesniük. A fekete rabszolgaság az Andokban nem volt jellemzó, többnyire háziszolgaként tartották óket a spanyolok, elvétve egyegy nagybirtokon tértek csak át a fekete munkásokra az indiánok helyett. Ezekben a völgyekben, illetve a tengerparti városokban ma is élnek a feketék leszármazottai.

A gyarmati uralom évszázadai alapvetóen nyugalomban teltek, csak elvétve volt példa felkelésekre, zendülésekre (ezek közül kiemelkedik Juan Santos Atahualpa felkelése az ôserdei területeken, 1742-1756). A kreol és indián elit közötti egyre mélyülő szakadék, illetve az indiánok adóztatásának újabb, megalázó formái azonban a XVIII. század végén elókészítették a talajt egy nagy indián felkelésnek, illetve késôbb a gyarmati uralom összeomlásának.

\section{Tupac Amaru felkelése és a felszabadító küzdelmek}

A Tupac Amaru-felkelés 1781. december 6-án, két spanyol adószedó felkoncolásával kezdôdött, a dél-perui hegyvidéken található Tungasucában. Az adószedôk a helyi nagybirtokos, a kuraka származású José Gabriel Condorcanqui házát is felforgatták, aki megelégelte az inzultust, és kardot rántott. Az adószedók a falu feletti hegygerincen levô kápolnába menekültek, de a lázadók ott sem kímélték óket. Condorcanqui ekkor meghirdette a spanyolok elleni általános harcot. Kinyilvánította, hogy ô az 1573-ban Cuscóban felnégyelt 
utolsó Inka, Tupac Amaru leszármazottja, és felvette a II. Tupac Amaru nevet. A felkelés híre a Középsố-Andok szinte teljes területét lázba hozta, a mai Ecuadortól Bolíviáig mindenütt voltak forradalmi megmozdulások.

A harc kezdetben jelentôs sikerekkel járt, elsốsorban a meglepetés ereje miatt, és mert jóformán tömegmozgalommá nôtte ki magát. II. Tupac Amaru zászlaja alá csapatostul jöttek indián származású, alacsony rangú katonák is, akikbôl hadsereget szervezett. A kreolokat azonban nem sikerült a forradalom mellé állítania, mint ahogy az is megbosszulta magát, hogy katonailag nem volt kellôen elốkészítve a felkelés. A britek ugyan támogatták a felkelôket a spanyolokkal szemben, ám ez a támogatás már csak azért sem lehetett elégséges, mert a kikötók végig spanyol kézen maradtak, a felkelés csak a hegyvidékre terjedt ki. Végül egy év múlva II. Tupac Amaru csapatait a gyarmati hadsereg szétszórta, a vezetốt pedig Cusco fớterén éppúgy felnégyelték, akár évszázadokkal korábban elốdjét. A felkelés a mai Bolívia területén még közel egy évig tartott. A felkelés emlékét az andokbeli népi hagyomány ma is ôrzi (a témával kapcsolatban lásd Kardulesz Rita írását, kötetünkben).

A Tupac Amaru felkelés leverését minden korábbinál véresebb megtorlás követte, amely nemcsak a felkelố családok, hanem általában az indián származású nemesek, illetve a felkelố indián faluközösségek ellen irányult. A gyarmati uralom korábbi alapját képezó kettốs társadalom megszúnt. Gondolhatnánk, hogy a megváltozott helyzet vezetett az andokbeli országok függetlenségi törekvéseihez: a kreol elitnek nem volt tovább szüksége a mérleg nyelvére, azaz a spanyol alkirályra. Valójában azonban az Andok országaiban a kreol elit a lehetố legtovább ragaszkodott a gyarmati rendszerhez, a spanyol hadsereg ugyanis védelmet biztosított egy újabb indián felkelés ellen.

Amikor Napóleon megszállta Spanyolországot (1808), a latinamerikai gyarmatok rövid idôre de facto függetlenné váltak. Több alkirályságban a kreol elit ezt liberális reformok, illetve a tényleges 
függetlenség kivívására igyekezett kihasználni (Cádizi alkotmány 1812, Argentína függetlensége 1816, Kolumbia 1819, Mexikó 1821). Bár Cuscóban (1812-14), La Pazban (Murillo-felkelés 1809) Quitóban (1809) és másutt is voltak függetlenségi megmozdulások, 1814 után a Középsô- Andokban megerôsödött a restaurálódó abszolutista spanyol hatalom. Peru csak 1821-ben, Bolívia pedig 1825-ben vált önálló állammá, miután San Martín plebejus csapatai délrôl, (az akkor már független) Argentínából, Simon Bolívar csapatai pedig Kolumbia felól „felszabadították” ezeket a területeket, és az ayacuchói csatában (1824), Antonio Sucre vezetésével döntố gyôzelmet arattak a spanyol gyarmati hadsereg felett. A harcokban az indiánok nem vettek részt, a limai és felsô-perui kreol elit pedig megosztott volt, sokan a felkelôket, mások a spanyolokat támogatták.

A mai Ecuador vidéke a felszabadítási küzdelmek után NagyKolumbiához került; ez a terület Bolívar halála után, 1830-ban szakadt le és lett önálló állam.

\section{A független államok XIX-XXI. századi története}

A függetlenségi háborúk után létrejött latin-amerikai országok nem nemzetállamok voltak: területükön különbözô nyelveket beszélô ôshonos népcsoportok is éltek, miközben az államnyelv minden volt spanyol gyarmaton a spanyol maradt. A három andokbeli állam, Ecuador, Peru és Bolívia annyiban sajátos, hogy itt a lakosság túlnyomó többsége, becslések szerint 85-95 százaléka indián származású volt a függetlenség hajnalán. Az indiánok többsége akkoriban is kecsuául beszélt, igaz, Bolíviában már akkor többmilliós ajmara kisebbség is élt. A hatalomra kerülố kreol elit többnyire a felvilágosodás talaján állt, és fokozódó türelmetlenséggel nézte az indián lakosság babonának nevezett vallási rítusait, hagyományait. A kecsua nyelv és indián hagyományok kiszorultak a templomokból, az oktatásból és a nyilvános reprezentációból (lásd Juan Carlos Estenssoro 
írását, kötetünkben). Mindehhez a fokozódó gazdasági elnyomás is társult: a szabad verseny és a piacgazdaság jegyében megszúnt az indián közösségi gazdálkodás gyakorlata, a kreol birtokosok egymás után vásárolták fel az indián kisgazdák földjeit, akik így mezőgazdasági munkásokká, cselédekké váltak (lásd Carlos Ivan Degregori és Andrés Guerrero írását, kötetünkben).

Az új államok gyors ütemben alakították ki nemzeti identitásuk alapelemeit, amely alapvetôen a szabadság és függetlenség kultuszán nyugodott. Gyors ütemben, néhány hónap alatt elkészültek a nemzeti zászlók (többnyire trikolór), nemzeti címerek, himnuszok. A felszabadító háborúk hôseirốl országokat (Bolívia), városokat (pl. Sucre) vagy nemzeti pénzt (Boliviano, Sucre) neveztek el.

Az államalkotó kisebbség a kreol, azaz a spanyol származású latinamerikai volt, amely a XIX. század végétôl tudatos bevándorláspolitikával is igyekezett erôsíteni a fehér elem nagyobb számarányát az Andok térségében. A bevándorlók többsége (akárcsak az USAban vagy Argentínában) olasz, német vagy közép-európai volt, akik azonban hamar elspanyolosodtak, és a pozitív diszkriminációnak köszönhetôen az indián származásúaknál magasabb társadalmi státusúvá váltak. Ezenkívül fốleg Peruban jelentốs volt a japán migráció is, leszármazottaik ma egy kb. 300 ezer fốs közösséget alkotnak. A mai andokbeli országok városi lakosságának identitásában fontos szerepet játszik a bevándorló-tudat, azaz, hogy az ôseik sok helyrốl érkeztek, de ók maguk már ecuadoriak vagy peruiak, mert itt születtek, nôttek fel, és az adott ország polgárai.

Az egyes országok nemzeti elitje nem habozott háborút indítani, ha az ország érdekei megkívánták: a XIX. század minden évtizedére esett néhány háború Latin-Amerikában. Peru sikerrel védte meg guano-szigeteit a spanyolokkal szemben (callaói csata, 1866), a guano évtizedeken át az ország gazdagodását segítố fontos exportcikké vált. Az Andok térségében a legnagyobb jelentôséggel az 1879-es ún. salétromháború járt. A puskaporgyártáshoz (és sok máshoz) szükséges stratégiai ásványkincs nagy mennyiségben fordul 
elố a tengerpart-melléki hegyvidéki sivatagban (Antofagasta tartományban), mely abban az idôben Bolíviához tartozott. Bolívia és Peru szövetségben harcolt Chile ellen, ám a chilei haderô felkészültebb volt, előbb vízen, majd szárazföldön arattak döntố sikereket, 1881-ben Limát is elfoglalták. Bolívia elveszítette a salétrommezóket és teljes tengerpartját, és Peru is veszített délen néhány tartományt. A salétrommezốknek jelentôs szerepe volt abban, hogy Chilében a XIX-XX. században erôs és tehetôs középosztály jött létre (lásd Larissa Adler Lomnitz írását, kötetünkben), míg Bolíviában állandósult a tốkehiány és a szegénység, Peruban pedig szélsôséges társadalmi különbségek alakultak ki. Bolívia késóbb a Paraguay ellen vívott háborúban (1932-35) elveszítette a Gran Chaco területeit, összességében mai területe alig fele annak, ami a függetlenség kikiáltásakor volt. Ecuador és Peru a XX. században vívott egymással több háborút, ezek kiváltó oka egy másik stratégiai nyersanyag, az ecuadori ôserdôben található kốolaj volt. 1941-ben Peru egy gyors támadással megszerezte a kérdéses területeket, majd az Egyesült Államok beavatkozásának köszönhetôen fegyverszünet állt be, melyet a kilencvenes évekig gyakran szakított meg hosszabb-rövidebb fegyveres incidens. A területszerzés ellenére a kôolajmezók java része Ecuadorban maradt, mert ezek többségét a negyvenes években még nem ismerték.

A XX. században az andokbeli országok belpolitikáját a jobb- és baloldal küzdelme jellemezte, amely küzdelem gyakran fegyveres konfliktussá is fajult. Bár Peruban a marxista APRA (és más centrista vagy baloldali mozgalmak) többször kormányra kerültek, illetve 1968-80 között a puccsal hatalomra kerülố baloldali Forradalmi Kormány diktatúrája volt hatalmon (Juan Velazco, majd 1975-tôl Francisco Morales vezetésével), az Andok országait a múlt évszázadban többnyire az USA által támogatott jobboldali kormányok vezették. A leninista vagy maoista ellenzék sokszor nyúlt a fegyveres harc eszközéhez, például Bolíviában az 1952-es felkelés vagy Che Guevara balsikerú fellépése 1966-ban, Peruban az Abimael Guzmán 
vezett Fényes Ösvény (Sendero Luminoso) az 1970-80-90-es években. A forradalmi marxista erốk ellen az USA által támogatott diktatórikus rezsimek léptek fel, Bolíviában 1964-82 között, Ecuadorban a 70-es években.

A nyolcvanas években mindhárom országban konszolidálódott a parlamenti demokrácia, bár a lelkesedést a kilencvenes években általános csalódottság és kiúttalanság váltotta fel; ezt jelzi a politikai irányzatok gyakori váltakozása, új formációk folytonos létrejötte. Peruban például a jobb-, majd a baloldal kormányzati ciklusa után 1990-ben a minden politikusban csalódott peruiak a jóformán ismeretlen perui japán származású jelöltre, Alberto Fujimorira szavaztak, akit (a választási rendszer manipulálásával) kétszer is újraválasztottak; jelenleg Japánban, önkéntes számúzetésben él. Ecuadorban 1998 és 2000 között a többször nevet és formációt váltó Népi Demokratikus Párt nemzeti-szociáliskeresztény, egyszerre jobb-és baloldali kormánya került hatalomra, a múvelt (ma a Harvardon oktató), arab-német származású Jamil Mahuad Witt vezetésével. Az ország 2000-re pénzügyi káoszba süllyedt; a nemzeti bank elnökét 8 év börtönbüntetésre ítélték, az országban pedig a dollár lett a hivatalos fizetôeszköz.

Az államszocializmus bukása kihúzta az ideológiai talajt a latinamerikai marxista mozgalmak lába alól, ugyanakkor megerôsödtek az ôshonosok jogaiért küzdố mozgalmak. A kilencvenes években Ecuadorban, Bolíviában egymást érték az indián jogvédô mozgalmak erốdemonstrációi, igaz, ezek többnyire nem fegyveres küzdelmek, hanem (olykor erôszakos) tüntetések, tömegdemonstrációk, útlezárások formájában jelentkeztek. Az új évezredben az indián mozgalmak megtalálták az utat a parlamenti demokratikus képviselethez is. Napjaink politikai és közéletét a középpártok, baloldaliak és az indián mozgalmak diskurzusa jellemzi.

Bolíviában 2006-ban az indián származású, szakszervezeti múlttal rendelkezô Evo Morales Ayma, a Szocialista Mozgalom jelöltje gyốzött az elnökválasztásokon. Morales 2005-ben Tiahuanacoban 
Apu Mallkának, az indián népek királyának koronáztatta magát. Protekcionista politikával erôsíti az állami szerepvállalást a kôolajiparban és a földgázkitermelésben, földreformot hajtott végre, illetve 2006-ban meghirdette a kecsua és ajmara nyelvú oktatási programot.

Ecuadorban a hatalom fokozatosan a nemzeti és szocialista, az indián mozgalmak (CONAIE, Pachakutik) által is támogatott tömörülés kezébe került, amely 2007-ben választásokkal gyôzött. A venezuelai Hugo Chavezhez és a bolíviai Evo Moraleshez hasonló politikát folytató ecuadori elnök, Rafael Correa múködésére jellemzô, hogy új alkotmányozó nemzetgyúlést hívott össze, vagy hogy kiutasította az országból az IMF képviselôit.

A perui választásokat 2001-ben a magát indiánnak valló elnökjelölt, Alejandro Toledo nyerte; a 2006-os választásokon az APRA jelöltje, Alan García gyôzött, mögötte az ún. Nacionalista Pártot vezetô, indián származású Ollanta Humala végzett a második helyen. 